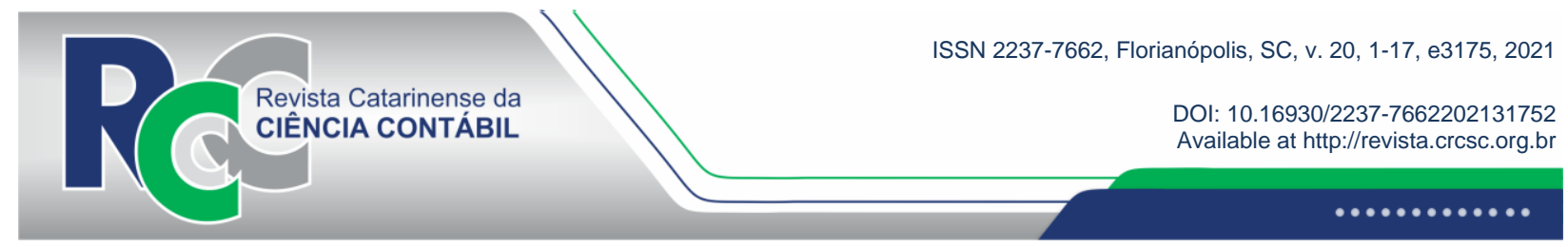

\title{
PROJECT-BASED LEARNING IN AN ACCOUNTING GRADUATE PROGRAM
}

\author{
TAÍS DUARTE SILVA \\ Federal University of Uberlândia. Address: Avenida João \\ Naves de Ávila, 2121 | Santa Mônica | 38408-100 | \\ Uberlândia/MG | Brazil. \\ (1) https://orcid.org/0000-0002-5972-8851 \\ taisduartes@yahoo.com.br
}

\section{EDVALDA ARAÚJO LEAL}

Federal University of Uberlândia. Address: Avenida João Naves de Ávila, 2121 | Santa Mônica | 38408-100 | Uberlândia/MG $\mid$ Brazil.

(1) https://orcid.org/0000-0002-7497-5949

edvalda@ufu.br

\begin{abstract}
Considering the relevance of choosing a teaching methodology on student learning, this study aimed to identify the benefits and limitations of project-based learning. In order to reach the proposed objective, we investigated the method's application in the Cost Analysis course at a Graduate Program in Accounting. The methodology employed included document analysis, observation, questionnaire application, and a focus group with the students. In addition, the analysis considered the development of all the methodology steps proposed by the literature, descriptively and qualitatively highlighting the students' perceptions. As research results, we verified that the students' opportunity to experience the practice is the benefit most emphasized. Furthermore, we highlight autonomy development, which is essential to solving the problem proposed in the project. Regarding the limitations, the time required to develop the projects stands out, and the need to deal with diverse situations that may arise during the projects' investigation and elaboration process. The results contribute by presenting the project-based learning methodology as an opportunity for students to develop theory and practice, experiencing real issues related to professional practice. Among this study's limitations we highlight the sample size, which included only one class during one semester and evaluated only the students' perspective. It is understood that these limitations may be considered in future studies to expand the sample and make comparative analyses between classes in different periods, also covering the view of teachers.
\end{abstract}

Keywords: Learning. Projects. Costs. Accounting.

Edited in Portuguese and English. Original version in Portuguese.

Received on 06/01/2021. Revised on 07/26/2021. Accepted on 08/26/2021 by Prof. Dr. Sérgio Murilo Petri (Editor-in-Chief) and Prof. Dr. Sandro Vieira Soares (Associate Editor). Published on 09/30/2021.

Copyright (C) 2021 RCCC. All rights reserved. Quoting parts of articles without prior authorization is allowed, as long as the source is identified. 


\section{INTRODUCTION}

The application of active methodologies in teaching has been discussed to implement changes that provide more autonomous student participation in their learning (Berbel, 2011). By employing these methodologies, we expect to have a more dynamic teaching environment in which the teacher has a facilitating role, and there is greater student involvement (Farias, Martin \& Christ, 2015).

Teaching methodologies that are considered innovative enable students to experience the real world, providing learning and skill development (Nicolaides, 2012). According to Morán (2015), the methodology choice must be consistent with the expected objective. As an example, the author mentions that if the intention is to seek more proactivity from the students, we should use a method that presents problem situations in which students are led to make decisions and evaluate them.

Among the various active methodologies proposed in the educational literature, this research investigates project-based learning (PBL). Such learning enables a learning process based on investigating real problems, which may be more meaningful to students and, consequently, provide a more favorable environment for knowledge acquisition (Behrens, 2014). Furthermore, project-based learning comprises projects that will require students to cooperate in solving situations they may encounter related to multidisciplinary topics (Bender, 2014). Moreover, this learning modality enables learning and the development of competencies, such as teamwork, communication, and critical thinking (Frezatti \& Martins, 2016).

Some studies (Bento, 2011; Berbel, 2011) stressed that the PBL methodology could provide greater student interest since there will be a need for investigations and search for solutions to the problem situations presented. However, there are still questions regarding the positive results the methodology can provide in the learning process (Kokotsaki, Menzies, \& Wiggins, 2016), which indicates the need for further studies on the possible benefits of PBL on learning (Guo, Saab, Post, \& Admiraal, 2020).

The literature also indicates that the application of PBL can take place in a wide variety of higher education academic areas (Guo et al, 2020). However, this study highlights Smith and Gibson's (2016) perspective, which emphasizes the PBL's potential for the business area, since students in this area prefer learning through practical content. Furthermore, particularly in Accounting undergraduate programs, there is evidence (Azevedo, Araújo \& Medeiros, 2017; Silva, Araújo, Vieira \& Bispo, 2018) that PBL promotes the development of professional competencies, improving the undergraduate education.

Aiming to contribute to the previous literature, especially regarding accounting education, this study intends to investigate the benefits and limitations of applying the ProjectBased Learning method to the Cost Analysis course offered in an Accounting Graduate Program.

Therefore, we intend to analyze the PBL method considering the Experiential Learning Theory, which advocates that learning is generated by knowledge created from the transformation of experience, generating knowledge or learning acquired through practice or observation (Kolb \& Kolb, 2005). Furthermore, the analysis under this theory is justified in the understanding that PBL is perceived as one of the methods that can be used in the experiential learning scope (Efstratia, 2014).

On the other hand, the accounting area analysis is justified based on previous evidence (Silva \& Bruni, 2017) that indicates the frequent use of passive methodologies and the need for teachers to seek practices that enable the student training for future professional performance. Moreover, students realize the importance of being in contact with practical methods and real cases (Viegas, Paes, Gouveia, Tractenberg, \& Kurtz, 2018), particularly in courses related to management accounting. 
By considering previous studies, such as those by Silva and Bruni (2017) and Viegas et al. (2018), we propose discussing the application of a methodology that may improve the accounting professional's training. We also intend to corroborate and move beyond previous findings (Azevedo et al., 2017; Silva et al., 2018) by investigating, in addition to the development of competencies, the general perception of students concerning other benefits and/or limitations regarding the PBL method use. Furthermore, we understand that it is a contribution to analyze the vision of graduate students, an audience that had not been investigated in the studies mentioned above and that will have the opportunity to experience an active methodology, which they can use in the future, since many of them work or intend to work in teaching.

\section{THEORETICAL REFERENCE}

\subsection{Project-Based Learning and Experiential Learning}

The project-based learning concept emerged in the 1920s, with Jonh Dewey and William Kilpatrick being the researchers responsible for the beginning of this type of learning that, at first, aimed at greater student participation, but, over time, also came to be seen from the perspective of investigation in search of knowledge (Behrens, 2014). For Barbosa and Moura (2013), this learning typology, taken as project-based learning, can be considered an active methodology that enables students to build competencies.

Synthesizing results that can be achieved with the use of PBL in higher education. Through a review study, Guo et al. (2020) observed that the methodology can interfere in cognitive aspects. For example, in the understanding of the subject taugh, in the affective aspect, which can be seen, for example, in the student's satisfaction during learning, and in the behavioral aspect, which can be seen in the development of skills/competencies. Based on these findings, the authors emphasized that PBL can contribute to a more innovative learning, meeting higher education demands in preparing students for professional practice.

PBL is characterized by inserting students in an investigation process that will enable them to acquire knowledge (Blumenfeld et al., 1991; Bell, 2010). Thus, this methodology can be understood as "a student-oriented approach, facilitated by the teacher" (Bell, 2010, p. 39), in which a main question is inserted to be investigated by the students with the teacher's monitoring, which should result in the elaboration of a project.

Lattimer and Riordan (2011) added that in PBL, students seek, through investigation, answers to real-world questions. In agreement, Barbosa and Moura (2013) point out that the existence of real cases is a presupposition of this methodology, which provides greater learning when compared to traditional teaching models. More broadly, Vesikivi, Lakkala, Holvikivi, and Muukkonen (2019) highlighted that PBL enables knowledge integration, and when adopted fully into the program's curriculum, it can contribute to reducing student retention early in the program.

The presence of real (practical) situations in the PBL development provides the involvement of students in the research process, instigating innovation to solve the proposed problem (Larmer \& Mergendoller, 2010). In this sense, its approach to Experiential Learning Theory stands out. According to Kolb and Kolb (2005), based on this theory, learning is discussed from the perspective of being obtained by experiences in a process with four principles, namely: experience, reflect, think, and act. According to the Experiential Learning Theory, the authors point out that learning is a process in which knowledge is created and recreated from the transformation of experience, generating knowledge or learning acquired from practice or observation (Kolb \& Kolb, 2005). 
According to Kolb and Kolb (2005), the experiential learning model comprises a cycle made up of four different integrated stages. These stages are composed of two modes related to 'Concrete Experience' and 'Abstract Conceptualization', and two modes related to 'Reflective Observation' and 'Active Experience'. Such stages are characterized by Gil (2008), meaning that the cycle begins with experience (Concrete Experience), which serves as a basis for reflection (Reflective Observation) that, combined with a theory (Abstract Conceptualization), leads to hypotheses being created to be tested in new situations (Active Experimentation). By bringing this discussion to the educational process, the author argues that experiential learning promotes the approximation between theory and practice, since it allows abstract concepts to have meaning when confronted with the practical situations of everyday life.

In this sense, Merriam and Bierema (2013) reinforce that experiential learning is related to the process that takes place when theories are associated to experiences, based on reflective practices, or practice-based learning. Thus, experiential learning comprises a set of mechanisms that offer individuals experiences capable of stimulating them to learn. In addition, however, it becomes relevant to reinforce that experiences have no guaranteed value, which implies that individuals may have different impressions regarding the same experience, because the experience is given by the interaction between their previous experiences with the present moment (Sonaglio, Godoi \& Silva, 2013).

Behr and Temmen (2012) argue that for an experience to be meaningful, it is important to recognize that knowledge should not simply be shared with people. Instead, they need to be encouraged to act on their learning. The research conducted by Ferreira, Leal, and Farias (2020) investigated the experiential learning provided by the teaching practicum in accounting. The results revealed that the graduate students' experiences in the internship activities contributed to their knowledge of teaching methodologies and how to apply them in their teaching practice.

In practical terms, we can see that the application of experiential learning tends to be hindered by some aspects, such as class size, time, and faculty resistance, as pointed out by Wurdinger and Alisson (2017). These authors investigated the perception of higher education teachers, who reported that they use few methods that can be considered experiential learning, even though they believe that this type of learning contributes to the development of students' skills.

In the specific analysis of experiential learning in accounting education, Gittings, Taplin, and Kerr (2020) found that the implementation of experiential activities in higher education institutions in Australia took place from the perspective of promoting skills that are demanded in the accounting profession. The authors also pointed out that experiential learning contributes to knowledge, student satisfaction, and the opportunity to apply theory into practice.

Given the above, this study aims to analyze the PBL application according to the Experiential Learning Theory, since the method involves problem solving and promotes the integration between theory and practice. Therefore, the next topic presents the steps adopted for the PBL development.

\subsection{Project-Based Learning Development Steps}

Regarding the PBL development, Blumenfeld et al. (1991) emphasized the existence of a guiding question to develop the activities and a final product generated by these activities as the projects' main aspects. Meanwhile, Larmer and Mergendoller (2010) pointed out that for projects to be of higher quality and relevance, it is necessary that students perceive them as significant and that an educational purpose is achieved.

Larmer and Mergendoller (2010) further advocated eight key characteristics for projectbased learning. For the authors, it is necessary that: i) students perceive that the content is meaningful; ii) students understand that knowledge is necessary to answer the problem; iii) there 
is a driving question that addresses key aspects of the topic to be learned; iv) students have active participation in choosing the project and thus see more meaning; v) there is the possibility of acquiring 21 st century competencies, such as critical thinking, cooperation, communication, creativity; vi) there is an in-depth inquiry into a real situation; vii) there is criticism and revision by the teacher and among the students to improve the quality of the final project; viii) there is an audience interested in the project giving more meaning to the projects.

It is noteworthy that, for the PBL development, it is necessary that some steps are performed, which are:

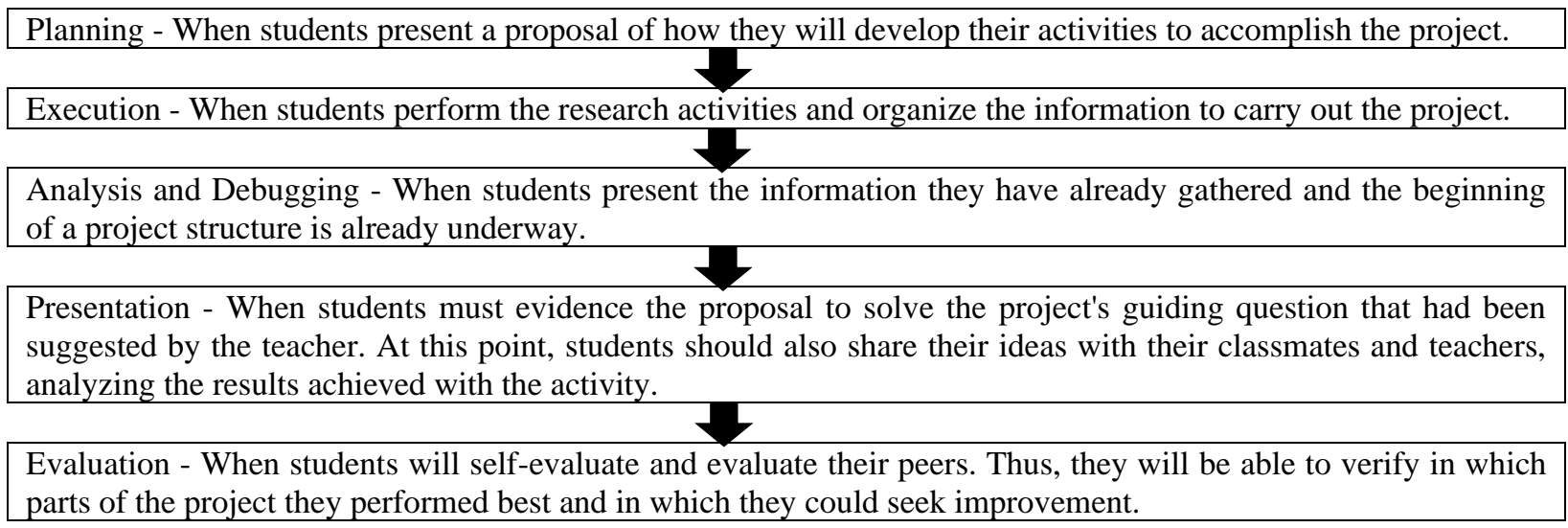

Figure 1. PBL Steps

Source: Based on Bento (2011)

It is worth noting that in PBL, the teacher's role should be to facilitate and guide, not just to convey information, as occurs in traditional classes, which can create challenges for which he or she must be prepared (Bender, 2014). Therefore, throughout the PBL application, the teacher should act as a mediator in the teaching process and should also clearly show how the learning and evaluation will take place (Nascimento, Behrens \& Torres, 2016).

Based on the PBL analysis, we can see that, for its development, the student is required to participate actively and to have a certain knowledge and persistence. In this sense, teachers are essential in helping students construct knowledge (Blumenfeld et al., 1991). As benefits the students will be able, from using PBL, to have a more meaningful learning and develop skills and competencies (Barbosa \& Moura, 2013).

Considering project-based learning, the study by Azevedo et al. (2017) aimed to identify knowledge, skills, and attitudes developed by Accounting students through PBL in the Business Budgeting course. According to the students' reports, the authors verified that there was a greater acquisition of knowledge in the accounting and management areas, that the main skills were teamwork, planning, and systemic vision, and that the main attitudes were commitment, proactivity, and respect for different opinions.

Similarly, Silva et al. (2018) investigated PBL in an Accounting program, namely, in the Controllership course. The researchers identified that students perceived the development of skills, competencies, and attitudes with the use of PBL, which can contribute to professional education. However, even with such benefits, students expressed a preference for traditional teaching approaches.

Finally, we highlight Parrado-Martínez and Sánchez-Andújar's (2020), which investigated the development of competencies associated with the use of PBL in a finance specialization program. The analysis we carried out through an experiment, over a two-year period, allowed us to verify significant improvements in the competencies analyzed (planning and organization skills, teamwork and cooperation, information management skills, oral 
communication skills, creativity, and innovation skills) after using PBL. Most of the students were satisfied with the methodology, highlighting that it is a motivating method that provides more autonomy and enables them to visualize theoretical aspects in real situations.

\section{METHODOLOGICAL PROCEDURES}

We developed a descriptive study with a qualitative approach to meet the proposed objective. The PBL was applied to the 'Cost Analysis' course in a stricto sensu Graduate Program in Accounting. We collected data through document analysis, observation, questionnaire application, and focus group (joint interview) with the participation of students enrolled in the course.

It should be noted that the researchers followed the entire process of applying PBL in the course. However, before starting this process, all the students were informed regarding the research and its objective, and also had access to the free and informed consent form, according to the institution's ethical provisions. Thus, the researchers started the data collection procedures only after the acceptance of all the students.

Still referring to the analyzed data, it is pertinent to point out that this study differs from others (Azevedo et al., 2017; Silva et al., 2018) in the audience choice, as it analyzes stricto sensu graduate students. This choice is relevant, because according to Leal and Oliveira (2018) this audience also needs to learn with other teaching methods that are not only the traditional ones and that present innovation, contributing to the development of other skills, in addition to learning. As for the Cost Analysis course, we selected it due to its characteristics that instigate the demand for real cases and connection with professional practice (Viegas et al., 2018), which is expected with the PBL use.

The sample comprises 14 students enrolled in the course, these being master's and doctoral degree students. It is important to point out that this course is offered as an elective course and has a workload of 60 hours. To begin the PBL development, the teacher responsible for the course presented, during one of the classes, what the PBL methodology is and how it would be used, highlighting the general steps to be followed in the technique application, as exposed in this work' s references (Bento, 2011). The teacher also explained that the theme to be worked on with the PBL was the "adoption of strategic cost management in organizations", which is the course's main theme.

The guiding question of the PBL proposed by the teacher to the class was, "How can the analyzed company use Cost Management for control, planning, and decision making process?". To enable the work on different topics that contemplate strategic cost management, the teacher indicated that the students should choose for the projects the following topics: i) determinants in price formation; ii) management and measurement of quality costs; iii) management of interorganizational costs; iv) analysis of competitors' costs.

For this activity, the students organized themselves into four groups, two of which were made up of four members and two were made up of three members. Next, each group chose a topic to develop the PBL. During the presentation of the PBL application in the course, the teacher indicated in more detail the steps (Table 1) that would be developed. 
Table 1

PBL Application Steps in the Cost Analysis course

\begin{tabular}{l|l}
\hline \multicolumn{1}{c|}{ Steps } & \multicolumn{1}{c}{ Activities } \\
\hline 1. Choosing the company to carry out the project & $\begin{array}{l}\text { The groups chose the company and verified the } \\
\text { feasibility of conducting the work. }\end{array}$ \\
\hline 2. Presentation of the initial project proposal (planning) & $\begin{array}{l}\text { A schedule was established for the presentations of the } \\
\text { initial project proposal and the selected company. }\end{array}$ \\
\hline 3. Presentation of the project's first version & $\begin{array}{l}\text { The groups presented the problematic identified for the } \\
\text { project, the structure, and planning for the development } \\
\text { (Analysis and Debugging). }\end{array}$ \\
\hline 4. Follow up & $\begin{array}{l}\text { The teacher responsible for the course scheduled } \\
\text { appointments with the groups to answer questions and } \\
\text { follow up on the project's construction. }\end{array}$ \\
\hline 5. Project Presentation & $\begin{array}{l}\text { The final presentation of the project was by means of a } \\
\text { video constructed by the groups. }\end{array}$ \\
\hline 6. PBL Evaluation & $\begin{array}{l}\text { Peer evaluation, self-evaluation and focus group (joint } \\
\text { evaluation) were conducted. Teacher evaluation for } \\
\text { each project also occurred. }\end{array}$ \\
\hline
\end{tabular}

Source: Research data (2019)

The evaluation step on the PBL use was performed through the application of a selfevaluation questionnaire, so that each student assigned a grade, considering his or her performance in the PBL development. We prepared this form based on the literature, considering the project development steps, encompassing: productivity, commitment, knowledge of the steps, teamwork, content, skills, and also the competencies developed.

The students also completed a peer evaluation form, that is, each student evaluated, by means of grades, all the components of the group in which he or she participated. The evaluation items aimed at measuring how each colleague performed regarding the proposed activities, if he or she met the deadline, participated as planned, actively collaborated, and what the overall performance was.

It is important to point out that the teacher participated in all the steps proposed for the projects' development, mainly to provide guidance on directions and to answer questions. Consultations were scheduled, through out-of-class meetings, according to the needs of the groups.

The focus group was conducted with all students, (indicated as P1, P2...) having them, at that moment, the opportunity to report their perception about the learning with PBL. The questions directed to the students allowed us to verify possible benefits obtained and skills developed with the use of this methodology, especially when compared to traditional teaching methods. We considered the way of planning and possible difficulties with the PBL use, as well as the perception of the practical experience linked to theoretical learning. The students also presented the main limitations evidenced in the development of the projects' steps.

With all the collected data organized, we presented the descriptive analysis referring to self-evaluation and peer evaluation. Then, we presented the information obtained through the focus group using content analysis, as proposed by Bardin (2011) with pre-analysis, exploration of the material, and results treatment, which allowed us to evidence the students' reports in two categories, indicating benefits and limitations in the use of the PBL method.

In summary, we have organized this study's results into three sections, as follows: (i) PBL development, revealing how the process took place throughout the semester, the presentations and results achieved by each group, all described based on observation and documentary analysis of the materials prepared by the students; (ii) PBL evaluation, indicating the results of the selfevaluation forms, peer evaluation, and evaluation of the course teacher; and (iii) benefits and 
limitations in the PBL application, which were demonstrated from the content analysis, performed on the students' report captured through the focus group.

\section{RESULTS ANALYSIS}

\subsection{PBL Development}

As presented in the methodology (Table 1), we developed six steps for the PBL application in the Cost Analysis course. After choosing the company to carry out the project, the students presented the project's initial proposal in class, on a previously established date. As a result, they highlighted the company's characteristics and the main aspects related to the use of strategic cost management, with each group addressing a specific theme. At this point, the teacher stressed the need to make it clear how the company might adopt the project that will be proposed, and that the students should be careful to detail all the steps that have been carried out and/or proposed. The students also made suggestions for the submitted projects from the other groups.

Furthermore, we found that of the four groups, two had their objectives already defined and the companies selected, the other two groups reported difficulties in selecting the companies. Thus, the teacher provided some guidelines and tips for the students to be able to access the organizations, as well as clarified some of the work's structural issues.

Moreover, the teacher scheduled a meeting with the groups to follow up on the development of the project's stages, and we noticed that the students had many doubts, which is due to their lack of knowledge regarding this methodology. The professor of the course gave the students a script with explanations on how the PBL works, highlighting the purpose of using it in the course and which aspects would be evaluated.

In the 'analysis and debugging' step, the students presented some information regarding the chosen company and some procedures that they would adopt to be able to answer the proposed problem. This presentation took place during class time and all students watched each other. At this point, the teacher passed on some information related to the presentation's structure, emphasizing the need to provide more detail on how the project would be elaborated.

It is important to note that in applying PBL in the classroom, the teacher should not be imposing, but should act as a guide so that students can solve situations more independently (Bender, 2014). This greater students' autonomy in search of their own learning should be encouraged by the teacher, and it is therefore necessary that he/she be prepared, because he/she will also play a different role if compared to the role played during the application of traditional teaching methods (Bender, 2014).

Later, in the 'project presentation' step, the students presented the whole process of developing the PBL and, to do so, they prepared a video that was shown to the whole class. The time of the video was delimited by the teacher, the students organized the recording considering the main steps of the project, including: company's characterization, problem situation, project proposal, and results presentation.

As described in the methodology, each group dealt with a specific theme that fell within the general theme of strategic cost management. Table 2 shows the summary of each project. 
Table 2

Summary of PBL results

\begin{tabular}{l|l|l}
\hline Groups - specific theme & Company's activities & Main results \\
\hline $\begin{array}{l}\text { G1 - determinants in price } \\
\text { formation }\end{array}$ & Education & $\begin{array}{l}\text { Analysis of the price formation determinants of the } \\
\text { tuition charged for the Accounting program at a private } \\
\text { educational institution, with a proposal for cost-focused } \\
\text { pricing. }\end{array}$ \\
\hline $\begin{array}{l}\text { G2 - management and } \\
\text { measurement of quality } \\
\text { costs }\end{array}$ & $\begin{array}{l}\text { Analysis of factors that affect the quality costs in the } \\
\text { elaboration of depilatory products with the proposal of } \\
\text { establishing a channel with customers to record } \\
\text { suggestions, as well as changes in some company } \\
\text { practices. }\end{array}$ \\
\hline $\begin{array}{l}\text { G3 - Interorganizational cost } \\
\text { management }\end{array}$ & $\begin{array}{l}\text { Agnalysis of the costs with the proposal of offering meals } \\
\text { in a company's unit, using its own resources located in } \\
\text { another place belonging to the same company. }\end{array}$ \\
\hline $\begin{array}{l}\text { G4 - Competitors' cost } \\
\text { analysis }\end{array}$ & $\begin{array}{l}\text { Analysis of the wholesale sector with the proposal of a } \\
\text { model for cost analysis of the company's competitors. }\end{array}$ \\
\hline
\end{tabular}

Source: Research data (2019)

After the presentation by the groups, the teacher reinforced that every project must have a well-founded analysis that effectively demonstrates the feasibility of execution, as well as the benefits of its implementation. It is also worth mentioning that, even with the specificities, each group contemplated a general theme (strategic cost management) with a previously established goal. In Larmer and Mergendoller's (2010) view, the existence of a main question and an educational goal are essential in the PBL development.

\subsection{PBL Evaluation}

The evaluation process of the PBL application analyzed in this study included the students' self-evaluation, the peer evaluation, and the teacher's evaluation. In other words, we tried to identify the students' perception of their own performance, considering the possible skills developed using the methodology, as well as their colleagues' performance. Table 3 presents the answers below.

\section{Table 3}

\section{Performance Self-Evaluation}

Productivity

I tried to know the work to be executed

$\begin{array}{rrr}\text { Max. } & \text { Min. } & \text { Avg. } \\ 10 & 9 & 9.75 \\ 10 & 8 & 9.61 \\ 10 & 8 & 9.18\end{array}$

I carried out the work with the established quality

$\begin{array}{lll}10 & 8 & 9.18\end{array}$

Average per item

\section{Commitment}

I know the proposed objectives for the work (PBL)

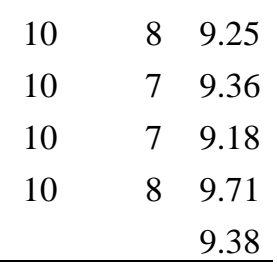

I executed my activities in line with the proposed objectives

I contributed to the improvement of the activities' execution

Average per item

\begin{tabular}{|c|c|}
\hline 10 & 8 \\
\hline 10 & 8 \\
\hline 10 & 8 \\
\hline
\end{tabular}

\section{Knowledge of the Work Steps}

I carried out the work with knowledge regarding the proposed procedures/steps

I sought to know the instructions necessary to carry out the work

I carried out the work according to the defined steps and objectives 
Average per item

Teamwork

I know the teamwork objectives

\section{0}

$8 \quad 9.71$

I interacted cooperatively with my team members

I facilitated the relationship among team members

$\mathrm{He} / \mathrm{she}$ actively collaborated in carrying out the activities

Average per item

\section{Content}

The PBL methodology helped me to memorize the content

10

$\begin{array}{ll}0 & 8.71 \\ 3 & 9.14 \\ 3 & 9.14 \\ & 9.00\end{array}$

I could see the practical application of the content studied in the organization

The application of the PBL methodology influenced the teaching and learning process

\section{Skills and Competencies}

\begin{tabular}{lrr}
\hline PBL contributed to developing analytical skills throughout the activity's development & 10 & 7.29 \\
I developed communication skills & 10 & 7 \\
The methodology assisted teamwork skills & 10 & 89.29 \\
PBL application contributed to problem solving and decision making skills & 10 & 590 \\
Average per item & 9.07 \\
\hline
\end{tabular}

Source: Research data (2019)

As we can see in Table 3, each student carried out a self-evaluation on all six items, assigning a score from 0 to 10 for each assertion. We can note that the highest average was centered on the productivity item, which shows the students' concern with meeting the deadline and the quality of the work developed. Teamwork also stands out, which suggests that there was a collaboration of each student with the group in the PBL development. Furthermore, we can verify that, in all items, the score was higher than 9, indicating that, in general, the students evaluated themselves well on the items presented.

Moreover, we asked the students to indicate a score regarding their overall self-evaluation in the PBL development. The lowest score was 8 , and 10 was the highest, resulting in a 9.15 average score. When considering the self-evaluation presented in Table 3, as well as the results achieved by the projects (Table 2), we believe the students had a good academic performance with the PBL application. In this regard, it is noteworthy that with the PBL application, students can actively participate, since they will be involved in the investigation and in the search for answering a guiding question (Larmer \& Mergendoller, 2010).

It is worth noting that the use of project-based learning promotes teamwork, as presented by Bell (2010) and Azevedo et al. (2017). Furthermore, the methodology should favor the development of competencies such as critical analysis, communication, leadership, and interpersonal relationships, as pointed out in the literature (Barbosa \& Moura, 2013; Larmer \& Mergendoller, 2010).

One aspect worth mentioning is that, despite the averages above 9 , we can see that, in the content item, there were minimum values below 5, which indicates that not all students perceived the effectiveness of using the methodology for a better content retention. We understand that this finding can be explained by the students' different perceptions of the use of active methodologies. As pointed out by Berbel (2011), students need to believe in the method if they are to derive benefits from it.

The students also answered a questionnaire that allowed each one to evaluate the other members of their group. This evaluation focused on the students' role in the PBL development. 
Table 4

Overall evaluation per student (peer rating)

\begin{tabular}{clrrrr}
\hline & & Group 1 & Group 2 & Group 3 & Group 4 \\
\hline \multirow{3}{*}{ He/she met the established deadlines } & Minimum & 10.00 & 8.00 & 6.00 & 10.00 \\
& Maximum & 10.00 & 10.00 & 10.00 & 10.00 \\
& Average & 10.00 & 9.67 & 9.15 & 10.00 \\
\hline \multirow{2}{*}{$\begin{array}{c}\text { He/she executed the activities in line } \\
\text { with the defined objectives/planning }\end{array}$} & Minimum & 8.00 & 7.00 & 5.00 & 8.00 \\
& Maximum & 10.00 & 10.00 & 10.00 & 10.00 \\
& Average & 9.50 & 9.50 & 8.58 & 9.33 \\
\hline \multirow{2}{*}{ He/she sought to know the } & Minimum & 10.00 & 7.00 & 3.00 & 8.00 \\
instructions necessary for the work & Maximum & 10.00 & 10.00 & 10.00 & 10.00 \\
& Average & 10.00 & 9.58 & 8.54 & 9.33 \\
\hline \multirow{2}{*}{ He/she actively collaborated in } & Minimum & 9.00 & 7.00 & 5.00 & 9.00 \\
& Maxrying out the activities & 10.00 & 10.00 & 10.00 & 10.00 \\
& Average & 9.83 & 9.50 & 8.69 & 9.67 \\
\hline \multirow{3}{*}{ Indicate the overall performance } & Minimum & 9.00 & 7.00 & 5.00 & 10.00 \\
& Maximum & 10.00 & 10.00 & 10.00 & 10.00 \\
& Average & 9.83 & 9.50 & 8.71 & 10.00 \\
\hline
\end{tabular}

Source: Research data (2019)

Table 4 presents figures segregated by groups, which consisted of three to four students each. Overall, the averages are close, with only Group 3 presenting lower scores, which indicates that the group was not able to work cooperatively as expected. We can also see that the highest averages were for the deadline, as identified in the self-evaluation, which confirms that the students made an effort to meet the demands on time.

Regarding the overall performance, we found that the evaluation scores of some students were lower than the self-evaluation scores. We understand that this is due to the difficulty of some students to work in groups.

The self-evaluation and the peer evaluation were added to the teacher's evaluation (verified by the researchers with the document analysis) for the constitution of each group's final grade. The teacher considered the submitted report as the project's result, as well as the final presentation given in class. Finally, on average, the students scored $84 \%$ of the total grade.

It is important to point out that in the PBL evaluation process, the use of more than one modality is recommended to consolidate the analysis of the students' performance. In the case presented, we used self-evaluation, peer evaluation, and evaluation of the steps by the teacher in charge of the course.

\subsection{Benefits and Limitations in Applying PBL}

In an attempt to understand the students' perceptions, we carried out a focus group, and in this section we present the results. Initially, we analyze the positive aspects (benefits) and negative aspects (limitations) of the PBL methodology in comparison with traditional teaching methodologies. We can observe that experiencing the practice during the PBL development was a frequent aspect in the participants' speech.

P1: I think that the main aspect is to experience the practice, to know the reality out there that, sometimes, we only know the example from a book or an article, and the activity provided this contact. 
P2 [...] I found it very interesting, especially going to the companies to get to know the reality. We remain within this closed environment $[. .$.$] that I think, sometimes, we lose a$ little bit of the practice.

As evidenced in the literature (Berbel, 2011; Morán, 2015) the use of active methodologies enables students to learn with real situations, which can contribute to their learning (Nicolaides, 2012), being this experience of living the "real world" one of the premises of PBL (Lattimer \& Riordan, 2011). Thus, experiential learning is perceived, according to which knowledge is generated from the transformation of experience, generating learning that is acquired through practice or observation (Kolb \& Kolb, 2005).

Another benefit mentioned by the students refers to the learning provided by the use of the methodology, which we can identify in the speech of two students.

P3: The main thing is not only to visualize, but to retain it. Because today I do not need to read a book or an article to remember what our theme is.

P4: I found the learning process to be much better [...] so, I thought that not only for our group, but also for the other groups, we were able to retain the content better.

P5: [...] I think that this methodology here is much more effective. We need to listen to a professional, we need to bring practical examples, and doing this in the PBL format worked very well.

From the students' reports, we can conclude that the methodology, for some, effectively contributed to their learning regarding the theme investigated in the project. In this sense, there is agreement with previous literature (Barbosa \& Moura, 2013), which indicates that PBL can provide more learning when compared to traditional methods. However, we must point out that the perception regarding learning was not unanimous among the students, because, as identified in the self-evaluation scores, some students did not perceive benefits in using the methodology to retain the content. We understand that this perception was mainly associated with the fact that one student had already experienced in practice the topic that was being investigated. In this regard, it is worth noting that individuals can have different impressions of the same experience, because the current experience is given by the interaction between their previous experiences with the present (Sonaglio et al., 2013).

In contrast to the previous comments, some students highlighted limitations in the PBL application.

P1: I think one aspect for improvement is time. Unfortunately, it is the time of the course period and the assigned grade. I think it should have been a higher grade [...] because it was something we dedicated ourselves to since the first day of class.

P2: The negative aspect that I found, I do not know if it is because we work and live in other cities, I found that sometimes it was difficult for the team to meet.

P6: [...] a negative aspect that I think, that I see in this methodology, is the difficulty to apply it to all the contents. I do not think all of them would be applicable.

We note that some aspects are not directly related to the method, but to the conditions required to develop it. One aspect worth considering is that graduate students have more 
activities compared to undergraduates, which makes the time frame more relevant. Therefore, what could be reevaluated is the teachers' planning towards having more time in their own classes so that the students can organize the activities.

As seen in previous studies (Bender, 2014; Nascimento et al., 2016), the teacher has a primary role in organizing the methodology and must clearly indicate what the objectives to be achieved are and how they will be evaluated. Considering the comments, one issue that the teacher should carefully observe is the activities distribution and the evaluation method throughout the semester so that the students do not feel impaired.

Resuming the analysis, we can observe that one of the participants indicated that a limitation of the methodology would be that its use is restricted to some contents. Thus, we asked the students regarding its application in the Cost Analysis course, and they understood that PBL is recommended for this course. However, the students pointed out the lack of the project's implementation, as follows.

P7: [...] so, if we had a research group, for example, that associated both undergraduate and graduate students, specific for this kind of project, we could have more results.

P5 [...] following up the project's implementation would mature us even more because at each step you go deeper and deeper, you realize that the universe of information and knowledge you need to access is much larger than what is established at the macro step [...] I think that the implementation would bring more visibility, we will need to make many adjustments to make it work or to understand that it does not apply...

It is worth mentioning that the project implementation is inserted in the PBL steps However, due to some limitations, such as time and access to companies, the students did not have the possibility to implement the project effectively. We understand this is one of the biggest challenges when using PBL, because, to implement the project, we need organization and integration of the various agents involved. In other words, we need teachers, students, and even the external public that may be involved, which, in the business area, will probably be made up of business men and women.

Another aspect that presents a potential PBL contribution, i.e., a benefit, refers to the development of skills that the methodology can bring, which was perceived by some participants

P8: But I think the main aspect was the autonomy to solve a problem. Because I got a video application that I did not even know how to use and I had to create autonomy...

P3: It was the creativity... I have a view that all the members were important, highlighted creativity, and somehow conveyed knowledge of the topic investigated in the project.

P6: [...] I think an important difference of PBL is the possibility to develop different skills, interpersonal skills, creativity itself. It can even be more extrapolated than in a traditional seminar.

We can see that some comments are associated with the making of the video that was suggested by the teacher for the project presentation. The students evidenced that, because it was something different from what they usually use, they had to be more autonomous, which enabled them to develop other skills.

The literature describes the development of competencies and skills when applying active methodologies, highlighting the autonomy of students (Berbel, 2011; Farias et al., 2015). 
Moreover, the students' report corroborates findings from previous studies (Azevedo et al., 2017; Silva et al., 2018) that indicated the development of competencies and skills with the PBL use.

Finally, we present some general comments from the participants regarding their PBL use during the semester.

P5: Yes, it was interesting [...] what I take away as a lesson of group work in this project is that I think we can bring more autonomy within the group [...] we need to trust a lot in what each one delivers as their part...

P6: I think the project, at least, I had that perception. We have many ideas and we cannot do them all, to save the world. So, it was a challenge for us and also precisely this conflict of ideas.

We can infer that the reports are consistent with some active methodologies aspects. The conflict of ideas mentioned by a participant can be challenging, but as Berbel (2011) states, with the use of active methodologies, students are expected to be able to solve challenges, which are frequent in the real environment. Furthermore, as discussed by Frezatti and Martins (2016), teamwork is one of the possibilities that students may develop when working with methodologies that involve problem solving, as is the case with PBL.

\section{FINAL CONSIDERATIONS}

This study aimed to investigate the benefits and limitations of the Project-Based Learning method application in the Cost Analysis course offered in the Graduate Program in Accounting, and this methodology was applied during one semester. We found that the PBL application provided some challenges to the teacher as well as to the students. We point out that the methodology application requires the teacher to be able to deal with the students' questions and with the several ways they may present to answer the proposed question, besides the organization of the time for insertion in the course that, in the analyzed case, had other activities planned.

As for the students, we expect them to have a more active posture, since they will be dealing with practical situations that demand more proactivity. With the research, we could realize that teamwork enables the acquisition of skills to reconcile the different visions each group member may present, making interaction essential to the development of the activities and the stages of PBL.

We also noticed that one of the methodology's benefits is the opportunity to learn from a real context and with practical situations, which, consequently, can contribute to the content retention. Such a finding suggests that the study corroborates the Experiential Learning Theory, highlighting the importance of providing activities that allow students to learn from real cases.

As for the limitations, the students highlighted the little time they had to develop the methodology. This result resembles that of Wurdinger and Alisson (2017), which found that faculty also complain about the time to develop methods to enable experiential learning. We understand that this can be a complicating factor, which reinforces the need for planning, since the teacher will probably have to allocate more time for the students to meet and develop the work.

Students also reported the possibility of developing some skills, such as critical analysis, autonomy, teamwork, interpersonal relationships, and communication, which corroborates previous literature (Azevedo et al., 2017; Silva et al., 2018). However, as indicated by Berbel (2011), it is important that students feel interested and motivated, which makes it appropriate to 
work with projects that they perceive to be useful in practice. Besides the skills developed, the graduate students got to know a methodology they will be able to use when teaching, since many intend to pursue an academic career. Furthermore, we also highlight that the experience with PBL contributed to meaningful learning, as the graduate students actively participated in favor of their own learning.

In summary, the study brings contributions by highlighting positive aspects of the method, as well as challenges that should be considered by the teacher during the application. This is a methodology that differs from traditional methods and that can be adopted by teachers in search of greater student involvement. Moreover, we understand that the PBL can be even more beneficial in the accounting area, particularly in courses related to management accounting, by allowing students to have contact with organizations and their management practices.

Finally, we point out that the study has some limitations, such as having analyzed the application of the method in a single class and having considered only the students' perception. Besides being a research limitation, it is a limiting aspect in the methodology application, because in order for it to be used more effectively, it would demand changes in the academic curricula, aiming at a greater integration of the courses. Thus, future studies should investigate the methodology's application with a larger number of classes, with other courses, as well as analyze the perception of teachers who have already used and/or are using the method.

\section{REFERENCES}

Azevedo, Y. G. P., Araújo, A. O., \& Medeiros, V. C. (2017). Conhecimentos, Habilidades e Atitudes Desenvolvidas Pelos Discentes de Contabilidade Através da Aprendizagem Baseada em Projetos. Revista Contabilidade, Gestão e Governança, 20(1), 153-174.

Barbosa, E. F., \& Moura, D. G. (2013). Metodologias ativas de aprendizagem na educação profissional e tecnológica. Boletim Técnico do Senac, 39(2), 48-67.

Bardin, L. (2011). Análise de conteúdo. São Paulo: Edições.

Behrens, M. A. (2014). Metodologia de projetos: Aprender e ensinar para a produção do conhecimento numa visão complexa. Coleção Agrinho.

Behr, T., \& Temmen, K. (2012). Teaching experience - improving teacher education with experiential learning. International Journal on New Trends in Education and Their Implications, 3(3), 60-73.

Bell, S. (2010). Project-based learning for the 21st century: Skills for the future. The clearing house, 83(2), 39-43.

Bender, W. N. (2015). Aprendizagem baseada em projetos: educação diferenciada para o século $X X I$. Penso Editora.

Bento, E. D. J. (2011). Aprendizagem por projetos para o desenvolvimento de competências: uma proposta para a educação profissional. Dissertação (Mestrado em Educação), Pontifícia Universidade Católica de Campinas, Campinas.

Berbel, N. A. N. (2011). As metodologias ativas e a promoção da autonomia de estudantes. Semina: Ciências Sociais e Humanas, 32(1), 25-40. 
Blumenfeld, P. C., Soloway, E., Marx, R. W., Krajcik, J. S., Guzdial, M., \& Palincsar, A. (1991). Motivating project-based learning: Sustaining the doing, supporting the learning. Educational psychologist, 26(3-4), 369-398.

Efstratia, D. (2014). Experiential education through project based learning. Procedia-social and behavioral sciences, 152, 1256-1260.

Farias, P. A. M. D., Martin, A. L. D. A. R., \& Cristo, C. S. (2015). Aprendizagem ativa na educação em saúde: percurso histórico e aplicações. Rev. bras. educ. méd, 143-150.

Ferreira, L. V., Leal, E. A., \& Farias, R. S. O. (2020). Papel do estágio docência no desenvolvimento de competências didático-pedagógicas no contexto da pós-graduação em Contabilidade. Revista de Educação e Pesquisa em Contabilidade (REPeC), 14(2), 158-176.

Frezatti, F., \& Martins, D. B. (2016). PBL ou PBLs: a customização do mecanismo de aprendizagem baseada em problemas na educação contábil. Revista de Graduação USP, 1(1), 25-34.

Gil, A. C. (2008). Didática do ensino superior. São Paulo: Atlas.

Gittings, L., Taplin, R., \& Kerr, R. (2020). Experiential learning activities in university accounting education: A systematic literature review. Journal of Accounting Education, 52, (100680), 1-13.

Guo, P., Saab, N., Post, L. S., \& Admiraal, W. (2020). A review of project-based learning in higher education: Student outcomes and measures. International Journal of Educational Research, 102, 1-13.

Kolb, A. Y., \& Kolb, D. A. (2005). Learning styles and learning spaces: Enhancing experiential learning in higher education. Academy of management learning \& education, 4(2), 193-212.

Kokotsaki, D., Menzies, V., \& Wiggins, A. (2016). Project-based learning: A review of the literature. Improving schools, 19(3), 267-277.

Larmer, J., \& Mergendoller, J. R. (2010). Seven essentials for project-based learning. Educational leadership, 68(1), 34-37.

Lattimer, H., \& Riordan, R. (2011). Project-based learning engages students in meaningful work: Students at High Tech Middle engage in project-based learning. Middle School Journal, 43(2), 18-23.

Leal, E. A., \& Oliveira, R. L. (2018). O método de estudo de caso aplicado no ensino em cursos de pós-graduação em ciências contábeis. Revista Contemporânea de Contabilidade, 15(35), 69-87.

Merriam, S. B., \& Bierema, L. L. (2013). Adult learning: Linking theory and practice. John Wiley \& Sons. 
Morán, J. (2015). Mudando a educação com metodologias ativas. Coleção mídias contemporâneas. Convergências midiáticas, educação e cidadania: aproximações jovens, 2(1), 15-33.

Nascimento, E. C., Behrens, M. A., \& Torres, P. L. (2016). A metodologia de projetos e o desafio na elaboração de novas possibilidades de propostas. Revista Contrapontos, 16(3), 518-533.

Nicolaides, A. (2012). Innovative teaching and learning methodologies for higher education Institutions. Educational research, 3(8), 620-626.

Parrado-Martínez, P., \& Sánchez-Andújar, S. (2020). Development of competences in postgraduate studies of finance: A project-based learning (PBL) case study. International Review of Economics Education, 35 (100192), 1-12.

Silva, C. M., Araújo, A. O, Vieira, E. R. F. C., \& Bispo, A. C. K. A. (2018). Análise da Efetividade da Aprendizagem Baseada em Projetos no Desenvolvimento de Competências no Ensino Superior de Contabilidade. Anais do Congresso UnB de Contabilidade e Governança, Brasília, DF, Brasil, 4.

Silva, U. B., \& Bruni, A. L. (2017). O que me ensina a ensinar? Um estudo sobre fatores explicativos das práticas pedagógicas no ensino de contabilidade. Revista de Educação e Pesquisa em Contabilidade (REPeC), 11(2), 214-230.

Smith, P. P., \& Gibson, L. A. (2016). Project-Based Learning in Colleges of Business: Is It Enough to Develop Educated Graduates? New Directions for Teaching and Learning, 145, 41-47.

Sonaglio, A. L. B., Godoi, C. K., \& Silva, A. B. (2013). Estilos de aprendizagem experiencial e aquisição de habilidades: um estudo com discentes de graduação em administração em instituições de ensino superior. Administração: ensino e pesquisa, 14(1), 123-159.

Vesikivi, P., Lakkala, M., Holvikivi, J., \& Muukkonen, H. (2019). The impact of project-based learning curriculum on first-year retention, study experiences, and knowledge work competence. Research Papers in Education, 35(1), 64-81.

Viegas, R. O., Paes, Á. L., Gouveia, T. A., Tractenberg, L. E., \& Kurtz, R. M. (2018). A Disciplina Contabilidade Gerencial sob a Perspectiva dos Egressos do Curso de Ciências Contábeis: Importância Atribuída e Conexão com a Prática Contábil. Sociedade, Contabilidade e Gestão, 13(3), 1-13.

Wurdinger, S., \& Allison, P. (2017). Faculty perceptions and use of experiential learning in higher education. Journal of e-learning and Knowledge Society, 13(1), 15-26. 